\title{
Taking the temperature of rights and freedoms: Zimbabwean secondary school students' knowledge about the African Charter of Human and Peoples' Rights and their support for its provisions
}

\author{
Ottilia Chareka† (St. Francis Xavier University)
}

\begin{abstract}
The African Banjul Charter is a cornerstone document promoting human rights education in Africa. As Zimbabwe is one of the signatory states to the Charter, a survey was conducted with 265 Zimbabwean secondary students to assess their knowledge of and support for the provisions detailed in the Charter. Fifty-six percent of the participants knew about the Charter and 59\% supported the Chart. Knowledge and support were found to be positively correlated. While gender did not influence responses, grade level was a significant predictor of knowledge and support for the Charter).

Résumé

La Charte de Banjul est le document de base pour la promotion de l'éducation des Droits de l'Homme. Comme le Zimbabwe a signé cette Charte, une enquête y a été menée auprès de 265 étudiants de l'école secondaire afin d'évaluer leurs connaissances et l'acceptation de la Charte. Cinquante-six pour cent des participants connaissaient la Charte et $59 \%$ y adhéraient. Les résultats de l'enquête montrent une corrélation positive entre connaissance et acceptation. Ils montrent également que bien que le sexe n'influence pas les réponses, l'année d'étude représente un indice important quant à la connaissance et l'acceptation de cette dernière.
\end{abstract}

The African [Banjul] Charter of Human and Peoples' Rights was first proposed at a meeting of the Organization of African Unity (OAU) in July, 1979 in Monrovia, Liberia. A draft Charter was adopted unanimously in June, 1981 in Banjul, Gambia at the OAU Heads of State meeting in Nairobi, Kenya and the Charter went into effect on October 21, 1986, after ratification by the majority of OUA member states including the newly independent nation of Zimbabwe. Ratification of the Charter was highly controversial and much debated during initial discussions, as well as after inception, as some countries felt that the Charter was forced on them.

Despite initial controversy, the Charter, alongside the 1948 Human Rights Declaration, is considered to be among one of the greatest achievements made by African countries, in terms of developing instruments for the protection and promotion of human rights in Africa. The Charter provides signatory African governments with a road map for promoting the teaching, learning and protection of legal and human rights in their respective countries. Article 25 of the Banjul Charter shows clearly the education goals articulated by Charter authors: "Parties have the duty to promote the charter through teaching, education and publication, 
respect of the rights and freedoms contained in the Charter and see to it that these freedoms and rights, as well as corresponding obligations and duties are understood" (OAU, 1981).

While it is a signatory to the Charter, the Zimbabwe government has failed to meet the obligations and duties agreed to in the Banjul Charter. The Charter clearly states that human rights education should be an important component of a flourishing democracy and human rights education should be a core component of the school curriculum. Human rights education must also be linked to local cultures if successful reconciliation, promotion of tolerance, acceptance, equality, conflict resolution and integrity among people of different ethnic backgrounds are to be achieved especially in a country as diverse as Zimbabwe.

Zimbabwe's population of 12 million is comprised of Black ethnic groups, White Zimbabweans and those considered to be 'other'. The Black Shona ethnic group is the largest at $64 \%$, the Black Ndebele ethnic group makes up 30\% while White Zimbabweans comprise less than 5\% and others less than 1\%. Shona, Ndebele and English are the official languages while English is the medium of instruction from daycare to the tertiary education level. However, more than 10 different language dialects are spoken. Given the diversity of culture and language in Zimbabwe, human rights education must be given paramount importance in order to foster democratic development, collaboration and understanding among ethnic groups. At present, though civil war has not broken out, the country is in the midst of great political, economic and social unrest mainly caused by the government and partially worsened by economic sanctions imposed by Western countries. The economy is in deep crisis with inflation in January and February, 2009 pegged at 10 sextillion percent, the highest inflation rates in the world (Mike, 2009) Unemployment was $80 \%$ in 2008, the third highest rate in the world after Nauru and Liberia, countries which recorded unemployment rates of $90 \%$ and $85 \%$ respectively (Index Mundi, 2009). High inflation and unemployment rates forced the country to dollarize the economy and now the economy is based on hard currency (forex) because the Zimbabwean dollar has become valueless.

Zimbabweans attained independence on April 18, 1980 after a bitter struggle and the country is considered to be one of the new 'democracies' in Africa. Attainment of independence by any country, in particular Zimbabwe, should have freed its citizens to exercise and to enjoy basic rights and fundamental freedoms but human rights and human rights education in particular have suffered in the volatile, repressive political, economic and social climate that has existed there since 1991. The situation in Zimbabwe with regard to 
human rights prior to November 2001 was somewhat better than it came to be in recent years. Non-governmental organizations, such as the Zimbabwe Human Rights Association and other sister organizations, had implemented human rights educational activities in schools and communities. In 2001, the government barred these organizations from participating in schools and suspended human rights and democracy education programs/activities run by non-governmental organizations in all schools (Center for International Disaster, 2001; The Financial Gazette, 2001). The Government directed schools to continue teaching human rights education from the school curricular documents but these documents were produced with very limited resources and were heavily censored by the government. The situation grew worse after a referendum on constitutional review failed in 2000. Since that time there has been an explosion of sustained media reportage on deteriorating human rights in Zimbabwe, violations that have affected both the citizens of Zimbabwe and foreigners.

In January and February, 2009, approximately 20,000 human rights violations were recorded, an alarming figure considering that most human rights violations in Zimbabwe are neither reported nor documented, especially in rural and remote rural areas. Zimbabwe is theoretically a 'free and democratic society' but there is large gap between theory and practice. It is therefore imperative that Zimbabweans know what their rights and freedoms are and know how and when to exercise them when rights and freedoms are violated or denied. With this in mind, secondary school students of Zimbabwe, future leaders of the country, were asked as citizens about their knowledge and understanding of their rights and freedoms as stated in the Banjul Charter despite the repressive state of the government. These students have grown up only under the repressive government. They are the future leaders who will take over running of the country; it was interesting to find out what knowledge of human rights they have as the next generation of leaders.

\section{THE STUDY BACKGROUND}

A study was conducted to explore Zimbabwean secondary school students' knowledge and understanding of the Banjul Charter and their support for the Charter. The sub-goal of the study was to find out whether or not human rights education in Zimbabwe reflects the extent to which the government has infused the school curriculum with human right topics.

The study aimed to find out whether students know how to exercise their rights whenever necessary and also know when their rights are violated and their freedoms denied. In particular, the emphasis was on secondary school students' knowledge, practical application of their rights and freedoms as outlined in the 
Banjul Charter and their support for the Charter. As someone who is Zimbabwean by birth, I had constant communication with my relatives and with school headmasters and teachers with whom I was communicating before I went to collect the data. I was assured that I could collect the data with no problems as the political situation was not that volatile. So originally I wanted to have students randomly selected from schools in both rural and urban areas in different provincial regions of Zimbabwe so that I could have a representative sample from all the geo-political and ethnic composition of the country. However, when I went to collect the data the situation quickly deteriorated and became very volatile in terms of the political and social environment. Most school administrators in urban areas whom I approached in order for their schools to participate refused to have their schools participate because they said I was more of an 'outsider' and equated me to people from non-governmental organizations. They said that the implementation of human rights and democracy pilot program and research on human rights or teaching about human rights by outsiders had been suspended by the present government's ruling party - the Zimbabwe African National Union Patriotic Front (ZANU PF). As for schools in rural areas, the situation was even worse than in urban areas. Rural schools were almost 'a no go area' because in some schools teachers were being beaten and were running away from their schools due to political violence that was taking place. For example, on July 10, 2002 it was reported, "Mapanzure high school near Masvingo was on Monday shut down indefinitely after some of the 50 teachers at the school were beaten by suspected supporters of the ruling ZANU PF party." (The Daily Newspaper of Zimbabwe, 2002). Again, it was reported, "political violence has hit Zaka district and 15 schools have lost teachers as suspected ZANU PF youths unleashed a reign of terror, beating up teachers... Obert Mujuru the regional director of education on Tuesday confirmed the incidents..." (The Daily Newspaper of Zimbabwe, 2002). This was a common trend in rural areas across Zimbabwe.

This constraint posed a great challenge for some of the initial variables included, rural-urban and ethnicity. I had to be pragmatic and changed the original plan. I ended up collecting data from one big secondary school in Harare, the capital city of Zimbabwe where I knew the administrators before. It should be noted therefore, that this is one limitation of this study that the sample was just from one geographical area and not very representative of the ethnic population composition and balance of urban and rural areas of the Zimbabwe. 


\section{METHOD}

The proposal to carry out this project went through and passed the University of New Brunswick ethics review board. I carried out a survey of 265 secondary students using a questionnaire with 29 questions with parts (a) and (b) related to the contents of the Banjul Charter. The questionnaires were distributed and collected on the same day after students had completed them in class. In every class students were given the questionnaires and took approximately 40 minutes to read through the questionnaire without completing it. Instructions and the questions were read again by the researcher while the students were listening. This was done to ensure that the students understood the items and also helped to standardize the administration of the survey instrument from one class to another. Students were well informed that this was not a test but the data was being used for research purposes only. The administrators at this school gave me permission because they believe in social justice and respect human rights and dignity.

Most students at this school were of Black Shona ethnicity, the dominant ethnic group in Zimbabwe. Only two students were of Black Ndebele ethnicity so, as mentioned earlier, ethnicity was not an important variable for the purposes of this study. Students were told not to identify their names or the school for confidentiality purposes. They were also re-assured that the information they provided was for the purpose of this research as explained in letters sent to the participants and a letter sent to their parents. Before the students began the questionnaire, they were also asked to hand in the consent form.

\section{Population and sample}

The sample was drawn from a population of $(\mathrm{N}=1427)$ students from forms 2,3 and 4. The questionnaire was completed by a sample of 265 students randomly selected. The school had a total student enrollment of over 2000 students from forms 1 to 4 . Form 1 classes were eliminated from participating in this study because they had not covered any human rights education given by the nongovernmental organizations which was more detailed since this was suspended in 2001 as mentioned earlier. The school had 10 or more classes with about 40-45 students in each form level. Therefore, the sampling procedures used were a combination of stratified and cluster sampling. The forms were used as the strata. Two clusters (classes) were then randomly selected from each form level. Table 1 below tabulates the population size, $\mathrm{N}$ and sample sizes, $\mathrm{n}$. 


\begin{tabular}{|c|c|c|c|c|}
\hline \multirow{2}{*}{ Form level } & \multicolumn{2}{|c|}{ POPULATION } & \multicolumn{2}{|c|}{ SAMPLE } \\
\hline & $\mathrm{N}$ & $\%$ & $\mathrm{~N}$ & $\%$ \\
\hline \begin{tabular}{|l|} 
form 2 \\
\end{tabular} & 492 & 34.4 & 66 & 25 \\
\hline form 3 & 489 & 34.3 & 75 & 28 \\
\hline form 4 & 446 & 31.3 & 124 & 47 \\
\hline Total & 1427 & 100 & 265 & 100 \\
\hline
\end{tabular}

Table 1 Distribution of the population and sample

\section{Instrument}

The questionnaire instrument used in this survey was composed of 29 questions with two components (a) and (b) to finding out the level of knowledge and support for the Banjul Charter (see Appendix A). The questionnaire was critically adapted from a questionnaire used in a similar study in Canada on "Students" knowledge of the Charter of Rights and Freedoms and their agreement with its provisions" by Echols, Ungerleider, Labar and Daniels in 1991. From the literature review carried out, I could not find any similar studies done in African countries. The Echol's et al questionnaire was modified using Zimbabwean examples to make it relevant for the Zimbabwean context. I first did an extensive study of the Articles of the Banjul Charter and then formulated and developed the questionnaire items following the contents of the Banjul Charter. The questionnaire items were organized around a certain right or freedom selected from the Banjul Charter to make sure it was appropriate for use in Zimbabwe and also to be useful for investigating the main theme of this study - Zimbabwean secondary students' understanding of the Banjul charter. A real-life scenario was created around a right or a freedom from the Banjul Charter. For example, item 1(a) was: All Zimbabweans Citizens should be taught about the African (Banjul) Charter of Human and Peoples' Rights and 1(b) was: Do you think it is the government's responsibility and duty to educate its citizens about human rights and their freedoms? The students were asked to select 'yes', or 'no' or 'not sure.' The questionnaire was also given to two colleagues in the Faculty of Education who had developed several instruments and worked in the area of citizenship and human rights education in Canada and abroad in developing countries. These educators also had strong knowledge about the Banjul Charter as they were also using it in some of their social studies undergraduate classes and some of their research and teaching projects. 


\section{ANALYSIS}

The Statistical Package for Social Sciences (SPSS) computer software and another statistical software R. was used for data analysis. ${ }^{1}$ I cross-tabulated the response variables by gender and form level. Language and ethnicity were not included as variables in the analysis as the data was collected from students who were predominantly Shona and who spoke the same language with little variations in their dialects. There were three responses to each question for both item (a) and (b) which were yes, no and not sure (see appendix A).The research instrument was written in English because, as noted, English is one of three official languages used in Zimbabwe in addition to Shona and Ndebele and is the medium of instruction in Zimbabwe from daycare to the tertiary level. The variable "age" was excluded since most students did not state their date of birth.

\section{RESULTS AND DISCUSSION}

This section presents analysis and discussion of the results. It should be noted that it was impossible to find similar studies of this nature as none seem to have been done in Zimbabwe or in any other African country. The findings of this study, therefore, are of great significance to Zimbabwe and to other African countries. A few studies exploring Canadian students' understanding of the Canadian Charter of Rights and Freedoms have been carried out and it is these studies which stimulated interest in carrying out this study in Zimbabwe.

Student respondents were aware of the Banjul Charter and even strongly support the notion that the overnment of Zimbabwe should educate its citizens about their rights and freedoms based on the Charter. In fact, the Banjul Charter is frequently made reference to in the media and also by non-governmental civic organizations in most African countries. This was reflected in analysis of Question 1. Item 1a - 96.9\% responded yes, $2.7 \%$ answered no and only $0.4 \%$ were not sure. This question had the highest percentage of the expected response for knowledge. For item 1b, 83.6\% responded yes, 8.4\% answered no and 8\% were not sure when asked if the Zimbabwean Government is required to educate its citizens about their rights and freedoms. The results for Question 2 were quite fascinating, as it dealt with the issues of human dignity and respect which were violated by the police. The expected response for this question was no, as the police did not have the right to strip-search Moyo. Only $15.1 \%$ answered no which was the lowest response rate among all the 29 items. $5 \%$ were not sure and $79.9 \%$ answered yes, the police had the right to strip search Moyo even though

\footnotetext{
${ }^{1}$ The author is grateful to the Atlantic Computational Excellence Network (ACEnet) for the use of its facilities for data analysis.
} 
they do not. Response to this question revealed a lack of understanding of the rights that are implied, rights that students should know about.

Question 23 (a) was of interest as the expected answer was yes, the woman had the right to refuse a police search of her apartment. $42.8 \%$ of respondents did answer yes, $7 \%$ were not sure and $50.2 \%$ answered no. Questions 2 and 23 were developed from sections in the Banjul Charter based on the rule of law, the right not to be detained for crimes not committed and the right not to be abused while in remand prison.

The majority of student respondents thought that the police had the liberty and the right to strip-search people or to search people's houses even if the police had no search warrants. They also thought it was the police's duty to arrest people without telling them why they were being arrested, or explaining their rights to them. The scenarios used in these items were very closely related to real human rights violation situations which take place in Zimbabwe. The rule of law would state that police do not have the right to strip search the men or search the woman's flat given the nature of the crimes that were committed and the situation at hand (see also question 24). Students relied on their prior knowledge and their everyday experiences, seeing the Police and the Army consistently violating people's rights to the extent that they consider that behavior to be the norm for Zimbabwean society despite the fact that the Banjul Charter states that people are entitled to human dignity and respect.

Prior knowledge is an important factor in any form of learning. Some scholars in the field of education, constructivists in particular, strongly believe that prior knowledge provides the basis for learning and is the medium used for interpreting what is around us in everyday life (Chareka, 2005; Chareka and Sears, 2005; Chareka and Sears, 2006; Peck \& Sears, 2005; Peck \& Sears \& Donaldson, 2008). Prior knowledge has been shown to be an important factor in learning and in meaning construction especially in new situations, when applying new learning in real life situations. Ausubel (1968) and Hartman (1991) point out that meaningful learning depends on organizing material in a way that connects it with ideas which exist within a learner's cognitive structures (see also, Hughes and Sears, 2004). Some believe that understanding learner's prior knowledge is important in the whole process of learning, teaching and applying what has been learned in real life situations (Driver \& Easley, 1978; Hughes and Sears, 1996; Windschitl, 2002).

Daily exposure to everyday human rights violations by uniformed officers in Zimbabwe seems to have created misconceptions or false prior knowledge in student respondents. This has been supported in reports produced by many human rights organizations both abroad and in Zimbabwe. The 
Zimbabwe Human Rights Association which showed that assault, unlawful killings, unlawful arrest and detention and remand abuses committed by the Police and the Army are on the increase and are seen as the daily norm in Zimbabwean society. In general, most Zimbabwean citizens were/are not challenging the government on these wrong-doings (Zimbabwe Human Rights NGO Forum, 2001.)

In 2002, Amnesty International Zimbabwe reported that victims of human rights abuses were systematically denied justice by the authorities' repeated and deliberate failure to bring the perpetrators to justice. State security forces, police officers, army officers and agents of the Central Intelligence organization (CIO) committed widespread human rights violation. More than 1,000 cases of torture and ill-treatment were reported in 2002 (Amnesty International Zimbabwe, 2002)

Question 4 and 5 used in this study were based on the freedom of assembly. Student respondents thought that the people in these scenarios had no right to assemble, to demonstrate, to express their opinions nor to criticize the government. $39 \%$ of student respondents gave the expected answer which was yes, 53\% chose no and 8\% were not sure. For Question 5, 43.9\% chose yes, 50\% chose no and $5.1 \%$ were not sure. Again, responses to these questions showed a lack of understanding about the rights that are implied, rights that students should know about. Their everyday experiences and prior knowledge might be influencing factors. Students are not accustomed to seeing citizens criticizing the government or demonstrating because of government's suppression against these activities.

Questions 3 and 6 were based on minority and cultural rights. The expected answer, 'yes', was given $78 \%$ and $76.2 \%$ respectively. $17.3 \%$ and $19.4 \%$ chose 'no' and $4.7 \%$ and $4.4 \%$ were' not sure'. Student repondents agreed that minority language and cultural rights needed to be respected and granted even to the minority White Zimbabweans.

Question 8 was based on freedom of the press and Question 9 was based on democratic rights - the right of an immigrant who had just gained Zimbabwean citizenship to stand for election. The expected answer was 'yes' and received $36.6 \%$ and $43.1 \%$ respectively. For question $8,54.8 \%$ answered 'no' and $8.6 \%$ were 'not sure'. The 'no' response indicated that students were not aware of freedom of the press rights. As for Question 9, the students did not seem to realize that once someone becomes a citizen, that person automatically enjoys all rights and freedoms just like any other Zimbabwean citizen as $53.9 \%$ was given for 'no' and 3\% were 'not sure'. 
Question 11 was developed around the right to health facilities and the notion that the government must provide health structures and services for its citizens For Question 11, 85.5\% responded 'yes', 10.5\% 'no' and 4\% 'not sure'. These responses indicate that students know that Zimbabwean citizens have the right to medical care. Questions 13 to 18 dealt with political and gender rights. On average, 55\% answered 'yes', 40\% 'no', and 5\% were 'not sure' indicating that students do not clearly understand political rights and gender rights.

Question 19 was developed around minority rights and mobility rights and the notion that Zimbabweans can work in any city or region of the country despite their ethnicity and region where they come from. Yes was chosen $66.2 \%$ and $68.8 \%$ respectively for Items 19 and 20, 'no' was chosen 29.8 and 28.2 respectively, while 'not sure' was chosen by $4 \%$ and $2 \%$ respectively. Response to question 20 showed that students were gender sensitive and knew about equality rights and the notion of equal pay for work of equal value. It was interesting to see this level of knowledge and support for this right given that the Banjul Charter does not explicitly articulate the rights of women in any outstanding manner. These results are similar to results reported in a Canadian study (Anderson, Kirkwood and Khan, (n.d.) which reported that grade 7 - 10 Canadian students supported the idea that Canadians should get equal pay for equal work despite their gender.

Question 21 dealt with dress and gender. 'No', the expected response was chosen by $25.7 \%$ of respondents, $70 \%$ chose 'yes' and $4.3 \%$ chose 'not sure'. The majority of the students, even female students agreed that females could not wear trousers, only males, and strongly supported the notion that the school board had the right to establish such a policy. Again this response seemed to be influenced by traditional Zimbabwean cultural practices and lived experiences. Women who wear trousers are seen to be challenging men. These women are normally stereo-typed as prostitutes, especially in rural areas. When reflecting on my life in rural Zimbabwe - I realized that I was raised, taught and believed that trousers are for men while dresses and skirts are for women. In Zimbabwe, though things are changing, especially in urban areas, clothes and roles (chores) are still mainly gender divided according to traditional cultural practices, especially in rural areas.

Responses to Question 22 (72.5\% “yes", $20.4 \%$ "no", 7.1\% "not sure") showed that students do believe that Zimbabwean citizens have the right to obtain and read any newspapers they want to read. Question 27 focused on the right to education for the 'girl-child' and the right for all children to be educated. $65 \%$ supported the notion that all children should have the right to education. However, when it came specifically to the Chuma family scenario used in 
question 27 which showed the family deciding that the boy should go to school and not the girl, the responses shifted drastically. Only 49.1\% wanted schooling for the girl-child while 50.9 did not. This is consistent with other studies which have shown that in most African countries including Zimbabwe, girls are more likely to be denied the right to education in preference to their brothers or males in general. The United Nations Fund for Population Activities (2005) states: "the gender gap in education has left nearly twice as many women as men illiterate. In the poorest regions more girls than boys are out of school and the gap widens at the secondary level."

In terms of security issues in the African continent, the Banjul Charter explicitly states that signatories to the Charter are to help to maintain peace and security and help other African countries to achieve this goal. Most of the Zimbabwean students did not agree with this provision and did not want the government of Zimbabwe to send troops to any other countries in Africa for security purposes - for Question 29 only $47.6 \%$ answered of yes while $50 \%$ chose no and $3.4 \%$ chose not sure.

Table 2 below shows the expected responses by form level for all questions. It should be noted that form level had a significant influence on the knowledge exhibited about the Banjul Charter and support for its provisions.

\begin{tabular}{|l|l|c|l|}
\hline Form level & $\mathrm{n}$ & Knowledge ( \% expected responses) & Support (\% expected responses) \\
\hline Form 2 & 66 & 51.2 & 50.6 \\
\hline Form 3 & 75 & 54.9 & 57.4 \\
\hline Form 4 & 124 & 58.6 & 63.5 \\
\hline
\end{tabular}

Table 2: Form level, knowledge of the Charter and agreement with its provisions.

Table 3 shows knowledge of the Charter and support for its provision by gender. Males had a mean score of $54.2 \%$ while females had 52.7\%. In terms of support for the provisions of the Banjul Charter, male students had a mean score of $60 \%$ while female students had scored $57.1 \%$.

\begin{tabular}{|l|c|l|c|}
\hline & $\mathrm{n}$ & Knowledge & Support \\
\hline & & \multicolumn{2}{|c|}{} \\
\hline Male & 128 & 54.3 & 60.0 \\
\hline Females & 137 & 52.7 & 57.1 \\
\hline
\end{tabular}

Table 3: Knowledge of the Charter and support for its provision by gender. 
T-tests were performed to see if there were significant differences between male and female students with respect to their knowledge about and support for the Banjul Charter. The T-test showed no significant difference between male and female students with respect to their knowledge and support of the Banjul Charter $(\mathrm{p}=0.471$ and $\mathrm{p}=0.213)$ respectively. Overall, of all the students from form 2 to $456 \%$ showed knowledge about the Banjul Charter and $59 \%$ supported the provisions of the Banjul Charter.

\section{IMPLICATIONS FOR EDUCATION}

These research findings have both theoretical and practical significance for curriculum developers and teachers in Zimbabwe and other African countries who work on human rights and citizenship education programs with special focus on the Banjul Charter. In the last 20 years there has been great and renewed interest in the discourse of human rights and citizenship education with most attention given to young people. This is important because human rights education is core or central to teaching of respect and tolerance especially in a culturally diverse country like Zimbabwe.

As discussed above, human rights education is a central component of full citizenship. Human rights and citizenship education should be taught as practice of real life in society. It is crucial for a citizen to understand one's rights, freedoms and responsibilities in order to attain full citizenship. The concepts of citizenship and democratic participation have long been viewed as rights and responsibilities connected to membership in a political, social, cultural and economic community. These concepts are an intertwined with autonomy and closely related to the notions of respect, tolerance, equity and social justice in any society. If people, in particular the young Zimbabwean citizens surveyed in this study, are not taught or do not understand their rights, fundamental freedoms and responsibilities then realizing the notion or concept of democracy will not become a reality. Young people around the world and in Zimbabwe are the leaders of tomorrow and will need to develop a strong foundational knowledge about human rights issues in order to take on leadership roles. If they are denied their autonomy and the notion of active democratic participation, then determining the 'real or right' temperature of human rights is both questionable and difficult. It is important that the government of Zimbabwe support human rights and citizenship education from elementary education up to institutions of higher education. After all, education is a basic human right. The Universal Declaration of Human Rights (1948) stipulates that:

Everyone has the right to education; Education shall be free, at least in the elementary and fundamental stages. Elementary education shall be 
compulsory. Technical and professional education shall be made generally available and higher education shall be equally accessible to all on the basis of merit... (Article 26.)

In addition, The 1996 International Covenant on Economic, Social and Cultural Rights states:

The States Party to the present Covenant recognize the right of everyone to education. They agree that education shall be directed to the full development of human personality and the sense of its dignity, and shall strengthen the respect for human rights and fundamental freedoms... It is also written in Article 28 of the Convention on the Rights of the Child, that:

State Parties recognize the right of the child to education... and ... shall... make primary education compulsory and available free to all...make secondary education available and accessible to every child ... make higher education accessible to all children (Office of the High Commission, 1989).

The African Charter on Human and People's Rights states that every individual shall have the right to education. Though not perfect, the Banjul Charter presents great opportunities for human rights education to be implemented and taught in Zimbabwean schools and other African countries.

\section{CONCLUSION}

From the above analysis and discussion it is evident that the students surveyed for this study have some knowledge of the contents of the Banjul Charter and support its provisions but mostly at the theoretical level. At the practical level these students seem to lack real understanding of their rights and freedoms. They also seem unable to transfer the knowledge they do have to the practical or real life situations presented in most of the scenarios used in this study. No matter what they had learned, it seemed to remain at a superficial level of application. It seems they think that their everyday experience of human rights violations in Zimbabwe is the norm for their society. Their prior knowledge seems to be constructed of misconceptions. Kapoor (2007) found that, in India, lack of knowledge about discrimination and human rights was detrimental to victims and that lack of knowledge was linked to cultural and political limitations which had been placed on human rights based education. The Zimbabwean secondary students in this study showed that they do not know most of the rights which would apply to them nor do they envision challenging those who violate their rights and freedoms. The findings indicate that if human rights education is to be taught properly in Zimbabwean schools, then teachers should move beyond 
teaching it at the theoretical level and should help students to envision practical solutions to advocate for their own rights and freedoms. Human rights education should be placed at the core of the curriculum with the concepts of respect and tolerance woven into all subjects. The government should allow nongovernmental organizations to offer human rights education as they did before the ban as most have the materials and expertise. This study showed that the Zimbabwean government is not fulfilling its duty as a signatory to the Banjul Charter. Great inconsistencies exist between what the government preaches as its intentions for human rights education and the reality as reflected in its poor human rights education programs.

Finally, studies of this nature should be carried out nationally with both youth and adult participants in Zimbabwe and similar research should be carried out in other African countries like South Africa, Botswana and Malawi to mention a few. These studies could be used to compare and contrast the presence and effectiveness of human rights and citizenship education programs as related to the concepts of respect and tolerance promoted by the Banjul Charter.

\section{References}

Amnesty International Zimbabwe (2002). Annual Report 2011: State of the World's Human Rights. Retrieved on July, 14, 2007 from http://web.amnesty.org/report2003/zwe-summary-eng

Anderson, R., Kirkwood, K.J. and Khan, S. B. (n.d). A survey of elementary and secondary pupils: Their knowledge and attitudes regarding Canada. London, Ontario: Faculty of Education, University of Western Ontario.

Ausubel, D. P. (1968). Educational Psychology: A Cognitive View. New York: Holt, Rinehart and Winston.

Bibby, R. and Posterski, D. (1985). The emerging generation: An inside look at Canada's teenagers. Toronto: Irwin.

Chareka, O. (September, 2005). Conceptions of democratic participation among recent African immigrants and native-born Canadians. Unpublished PhD Dissertation, University of New Brunswick, Fredericton, NB.

Chareka, O., \& Sears, A. (2005). Discounting the political: Understanding civic participation as private practice. Canadian and International Education, 34(1), 50-58.

Chareka, O., \& Sears, A. (2006). Civic duty: Young people's conceptions of voting as a means of political participation. Canadian Journal of Education, 29(2), 521-540.

Driver, R. \& Easley, J. (1978). Pupils and Paradigms: A review of the literature related to concept development in adolescent science. Studies in Science Education, 5, 61-84.

Echols, F.H., Ungerleider, C., Labar, C., and Daniels, L.B. (1991). Students' knowledge of the Charter of Rights and Freedoms and their agreement with its provisions. The Alberta Journal of Educational Research. Vol. XXXVII, (1), 49-69.

Hartman, H. J. (1991, February 22). Thinking about learning from the perspective of Bruner and Ausubel. Paper presented at the American Psychological Association Convention Symposium, Mid-winter Convention, San-Antonio.

Hughes, A. and Sears, A. (1996). Macro and micro level aspects of a programme of citizenship: Education research. Canadian and International Education, 25 (2), 17-30.

Hughes, A. and Sears, A. (2004). Situated learning and anchored instruction as vehicles for social education. In Sears, A. and Wright, I (Eds.), Challenges \& prospects for Canadian Social Studies. Vancouver: Pacific Educational Press.

Index Mundi. (2009). Zimbabwe unemployment rate. Retrieved on April 10, 2009 from: http://indexmundi.com/zimbabwe/unemployment_rate.html 
Kapoor, D. (2007). Gendered-caste discrimination, human rights education, and enforcement of prevention of atrocities Act in India. The Alberta Journal of Educational Research. Vol.53 (3), 273-286.

Office of the United Nations High Commissioner for Human Rights (1989). Convention on the Rights of the Child Retrieved on July 3, 2007 from http://www2.unhchr.org/english/law.crc.htm

Peck, C., \& Sears, A. (2005). Uncharted territory: Mapping students' conceptions of ethnic diversity. Canadian Ethnic Studies, 37(1), 101-120.

Peck, C., Sears, A. \& Donaldson, S. (2008). Unreached and unreachable? Curriculum standards and children's understanding of ethnic diversity in Canada. Curriculum Inquiry. 38(1), 63-92.

Sears, A., \& Hughes, A. S. (1996). Citizenship education and current educational reform. Canadian Journal of Education, 21(2), 123-142.

Mike, M. (2009). Zimbabwe's inflation rate estimated at 10 sextillion percent. Retrieved on April 10, 2009 from: http://stuff.blat.co.za/2009/02/15/zim_inflation/

The Daily Newspaper of Zimbabwe, July 10, 2002. Retrieved on July 11, 2002 from http://www.dailynews.co.zw/daily/2002/July/July10/5570.html

The Daily Newspaper of Zimbabwe, July 18, 2002. Retrieved on July, 2002 from http://www.dailynews.co.zw/daily/2002/July/July10/5570.html

The Financial Gazette, November 15, 2001. Retrieved on November 17, 2001 from http://www.africaonline.com/site/Articles/1,2,43104.jsp

The International Covenant on Economic, Social and Cultural Rights (1996). Retrieved July 3, 2007 from http://www.unhchr.ch/html/menu3/b/a_cescr.htm

The United Nations Fund for Population Activities (2005). Universal primary education and closing the gender gap in education by 2015 .

The Zimbabwe Human Rights NGO Forum. Retrieved July 8, 2007 from http://www.hrforumzim.com/frames/inside_frame_monthly.htm

Organization of African Unity (1981). African (Banjul) Charter on Human and Peoples' Rights.

Center for International Disaster Information (2001) Weekly Round-Up - IRINSA-45: November 16, 2001. Retrieved on November 19, 2001 from http://iys.cidi.org/humanitarian/irin/safrica/01b/ixl19.html

Windschitl, M. (2002). Framing constructivism in practice as the negotiation of dilemmas: An analysis of the conceptual, pedagogical, cultural, and political challenges facing teachers. Review of Educational Research, 72(2), 131-175.

Zimbabwe Human Rights NGO Forum (2001) Human Rights Monitor, no.14. May 2001. Retrieved on July 10, 2007 from http://www.hrforumzim.com/downloads/Monitors/HRMonitor14.rtf

ACKNOWLEDGEMENTS: I am grateful to and would like to thank Dr. Alan Sears of the University of New Brunswick, Fredericton, New Brunswick Canada for providing initial partial funding for this research and St Francis Xavier University for funding provided from the Start-Up Research Grant for my second trip to Zimbabwe. I am thankful to the journal Editor and the Reviewers for their constructive comments which helped to shape this paper. Finally, I would like to thank David Coyle the Research Outreach Coordinator in the Faculty of Education, St, Francis Xavier University who assisted me in the background with the nitty-gritty grammatical services that are always necessary for and are part of writing an article after getting comments from the reviewers and for proof reading my paper although any errors remain my own doing.

Ottilia Chareka $\uparrow$ was an Associate Professor in the School of Education at St. Francis Xavier University where she specialized in Citizenship Education, Multicultural Education, Global Education and Human Rights Education. 


\section{Appendix A.}

\section{Provide the information below but DON'T write you name or your school name. Read the following questions carefully and check in the appropriate box}

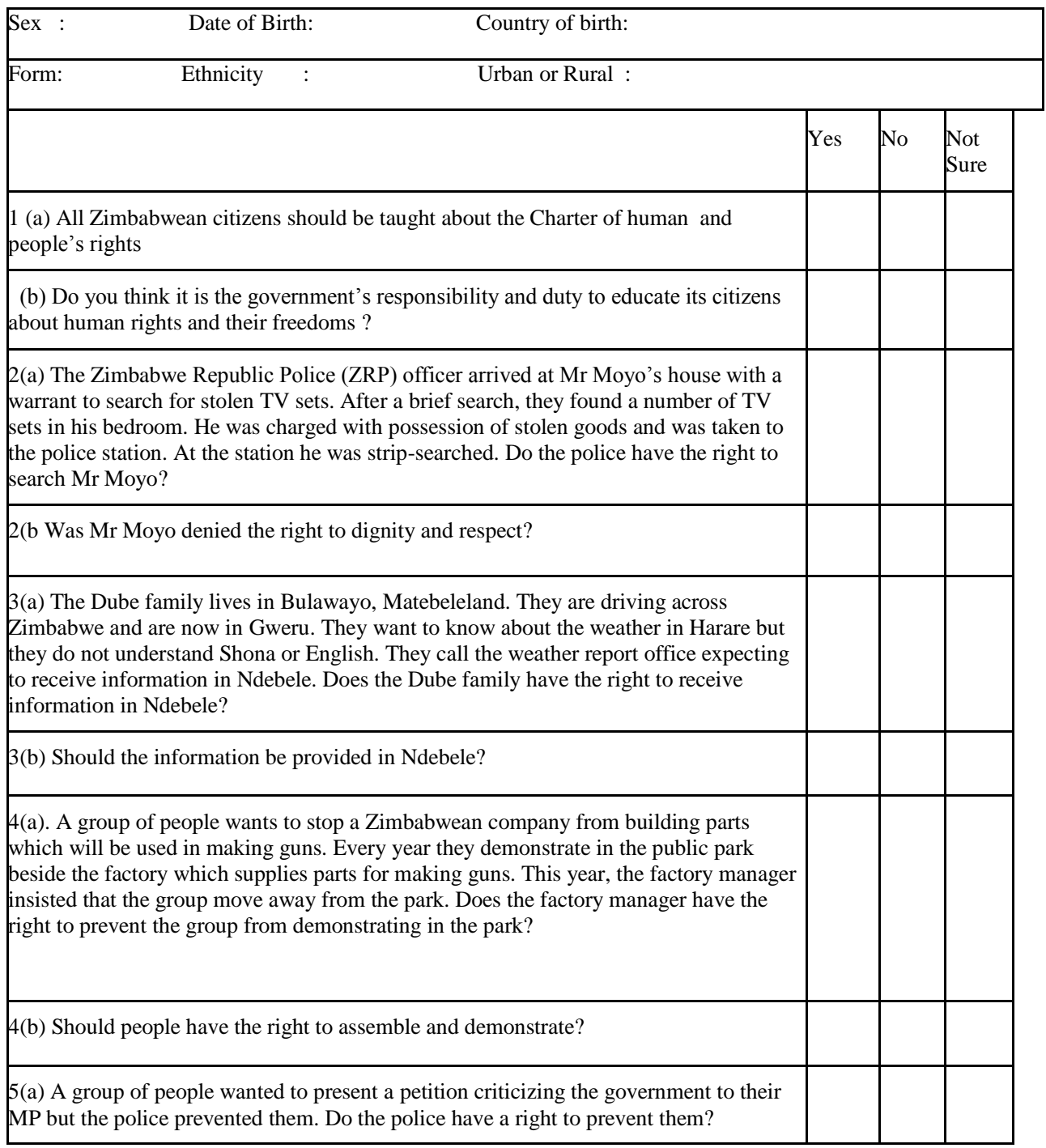




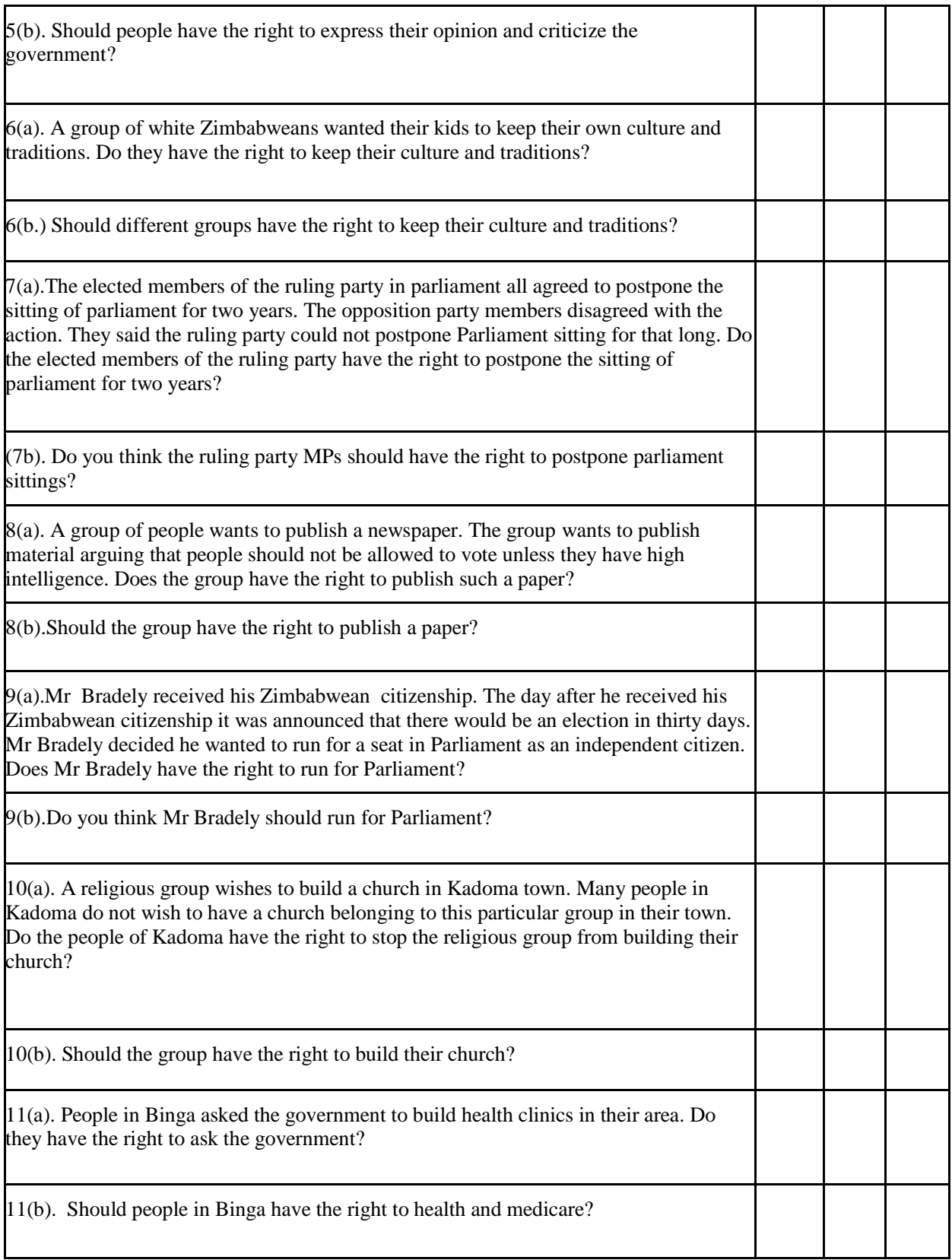




\begin{tabular}{|c|c|c|}
\hline $\begin{array}{l}\text { 12(a).A British woman immigrated to Zimbabwe in } 1940 \text { and obtained Zimbabwean } \\
\text { citizenship in } 1985 \text {. She went back to Britain last year at the height of farm invasions } \\
\text { and stayed for } 15 \text { months. Does the woman have the right to come back to Zimbabwe } \\
\text { under the same conditions as someone born in Zimbabwe? }\end{array}$ & & \\
\hline 12(b). Do you think the woman should have the right to come back? & & \\
\hline $\begin{array}{l}\text { 13(a).A teacher in Gokwe wanted to join a political party. The head said she could not } \\
\text { join the party as teachers were supposed to be neutral about politics. Does the head have } \\
\text { the right to stop teachers from joining a political party? }\end{array}$ & & \\
\hline 13(b). Should the teacher have the right to join any political party? & & \\
\hline $\begin{array}{l}\text { 14(a) Miss Rose has lived in Zimbabwe for thirty years without taking out Zimbabwean } \\
\text { citizenship. She decided to run as a member of parliament in her area. Does Miss Rose } \\
\text { have the right to run as a member of Parliament? }\end{array}$ & & \\
\hline 14(b). Should Miss Rose have the right to run as a member of parliament? & & \\
\hline $\begin{array}{l}\text { 15(a).Mr Samson was caught by two ZRP officers breaking into a hardware shop. He } \\
\text { was charged with breaking and entering. Mr Samson is deaf and wishes to have an } \\
\text { interpreter at his trial. Does Mr. Samson have the right to an interpreter at his trial? }\end{array}$ & & \\
\hline 15(b).Do you think Mr Samson should have the right to an interpreter? & & \\
\hline $\begin{array}{l}\text { 16(a). A small group of parents wish to protest a school policy. They intend to hold the } \\
\text { demonstration outside the school premises. People living near the school want to stop } \\
\text { the group from demonstrating. Do the parents have the right to hold the demonstration? }\end{array}$ & & \\
\hline 16(b).Do you think the parents should have the right to demonstrate? & & \\
\hline $\begin{array}{l}\text { 17(a). A woman went to her personnel officer of a major bank and asked to apply for a } \\
\text { particular position, she was told that she was not smart enough to take the next step and } \\
\text { get a promotion. Does the woman have the right to be considered for the position? }\end{array}$ & & \\
\hline 17(b). Should the woman have the right to be considered for the position? & & \\
\hline $\begin{array}{l}\text { 18(a). A primary teacher decided that her class should say the Lord's prayer every } \\
\text { morning. Two parents refused to let their children participate. They wanted them } \\
\text { excused from the room when the Lord's prayer was being said. Do the parents have the } \\
\text { right to have their children excused from the room when the Lord's prayer is being } \\
\text { said? }\end{array}$ & & \\
\hline ou think the children should have the ri & & \\
\hline
\end{tabular}




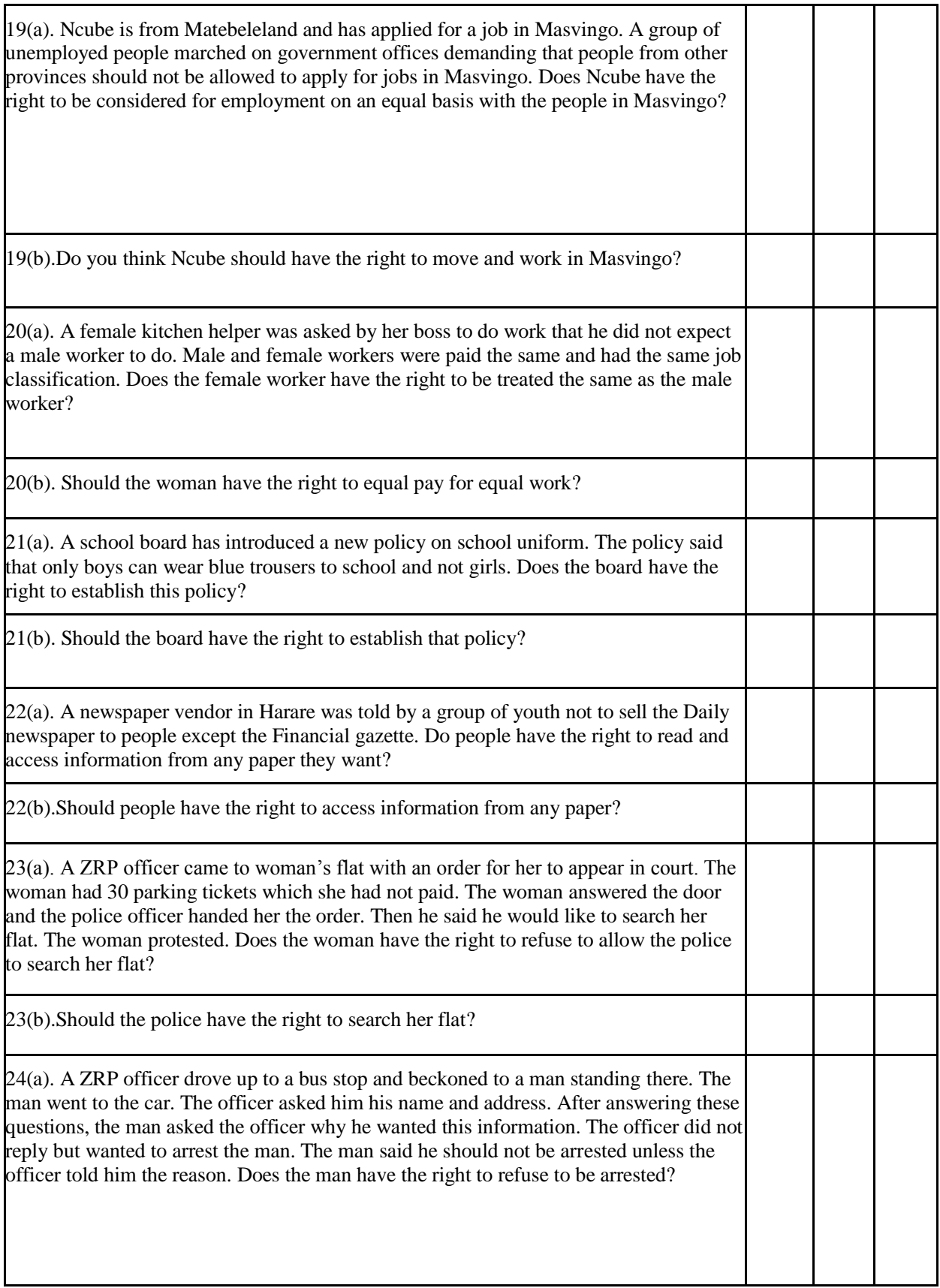




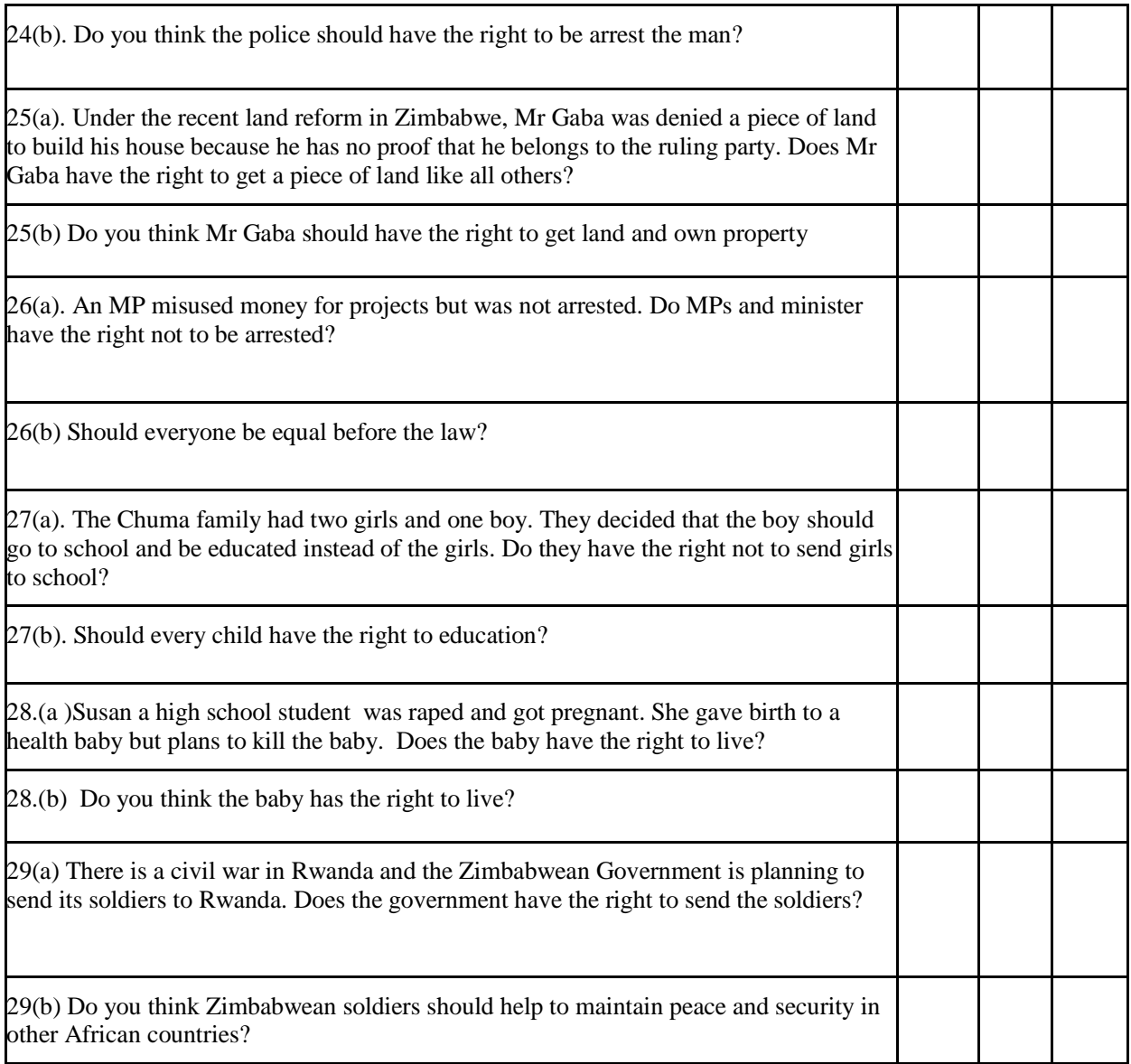

